\title{
Decreasing academic stress through problem-focused coping strategy for junior high school students
}

\author{
Nurma Eliyah Mujahidah ${ }^{\mathbf{1}}$, Budi Astuti ${ }^{2}$, Le Ngoc Ai Nhung ${ }^{3}$ \\ ${ }^{1}$ SMP Muhammadiyah Tanjungsari. Hargosari, Tanjungsari, Gunungkidul, Yogyakarta, 55881, Indonesia \\ ${ }^{2}$ Universitas Negeri Yogyakarta. Jalan Colombo No 1, Karangmalang, Yogyakarta, 55281, Indonesia \\ ${ }^{3}$ VNU University of Social Sciences and Humanities. 144- Xuân Thủy Street - Cầu Giấy - Hà Nội, Vietnam \\ * Corresponding Author. E-mail: budi_astuti@uny.ac.id
}

Received: 24 July 2019; Revised: 27 July 2019; Accepted: 2 September 2019

\begin{abstract}
The study aims at identifying the influence of the problem-focused coping strategy on academic stress decrease of VIII Grade students in junior high schools. The study is a quantitative research using quasi-experimental design with non-equivalent control group design. During the conduct of the study, the population of the participants was 180 students and the samples were gathered from the population by means of purposive sampling technique. The total number of the sample was 10 students, consisting of 5 students as the members of the experimental group and 5 students as the members of the control group. Then, the instrument that had been implemented in the group was the academic stress scale. On the other hand, the data analysis technique that had been implemented in the study was the non-parametric statistics namely the Wilcoxon test. The results of the study show that the problem-focused coping strategy has influence on academic stress decrease with the rate of significance $5 \%(\mathrm{sig} .=0.042, \mathrm{p}<0.05)$. Therefore, it might be safely concluded that the problem-focused coping strategy has influence on the academic stress decrease among the Grade VIII students in junior high schools.
\end{abstract}

Keywords: problem-focused coping strategy, academic stress

How to Cite: Mujahidah, N., Astuti, B., \& Nhung, L. (2019). Decreasing academic stress through problem-focused coping strategy for junior high school students. Psychology, Evaluation, and Technology in Educational Research, 2(1), 1-9. doi:http://dx.doi.org/10.33292/petier.v2i1.25

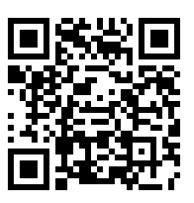

\section{INTRODUCTION}

Junior high school students certainly should attend a number of activities in their school. In addition to attending the learning process in the classroom, these students should also attend the extracurricular activities and this also applies to the Grade VIII students. Along with the progress of the continuous learning process, the increasing number of assignments and the limited time of learning process have caused the students to suffer from the academic stress. Academic stress refers to the stress that the students experience due to the learning process or the learning-related activities such as the pressure to get promoted to the higher class, the duration of learning process, the numerous number of assignments, the test scores, the decisions with regards to which department or which career that should be selected, the anxiety with regards to examination and the stress management (Barseli \& Ifdil, 2017; Nurmalasari, Yustiana, \& Ilfiandra, 2016; Putwain, 2007).

Based on the results of the observation during the fieldwork, the Grade VIII students do not only attend the academic activities but also the non-academic activities; for example, these students should attend the extracurricular activities outside their teaching-learning process. The Grade VIII students should join more activities in comparison to the Grade VII students; the Grade VIII students should be the members of the Internal Organization Caretaker but unfortunately not all of these students are able to serve as the members well. As a result, these activities make the students exhausted and not to mention these activities have taken a lot of their time. 


\section{Psychology, Evaluation, and Technology in Educational Research, 2 (1), 2019, 2}

Nurma Eliyah Mujahidah, Budi Astuti, Le Ngoc Ai Nhung

Based on the results of the interview with a group of Grade VIII students, it is found that these students have been complaining about the learning process in the school; for example, they complain about the full-day school system that requires them to be in the school until evening whereas in the same time the extracurricular activities have drained their energy. Then, the Grade VIII students also complain about the difficulties in understanding the lessons in the classroom. Some of the Grade VIII students suffer from several stress symptoms such as anxiety, boredom and tension. According to the results of the study (Astuti, Purnama, \& Laksana, 2019; Mumpuni \& Wulandari, 2010), stress might cause several impacts to the health and these impacts might be exhaustion due to work, psychosomatic symptoms, trauma and lack of attention.

In dealing with the academic stress, the junior high school that has been selected as the research site has never conducted any group guidance by using the problem-focused coping strategy. The Guidance and Counselling teachers have previously implemented other types and treatments and one of them is discussion. In conducting the discussion, the students seem to be less enthusiastic and do not pay attention to the discussion session and thus the discussion session does not flow fluently. The problem-focused strategy is a strategy that has been implemented in solving certain problems such as defining problems, defining alternative solutions, considering alternatives efficiently and selecting alternatives and actions. The problem-focused coping strategy is oriented toward the problem solution (Lazarus \& Folkman, 1984; Wardani, 2009).

Within the conduct of the study, the problem-focused coping strategy has been selected in order to focus on the problems and to find the alternatives for dealing with the problems (Bakhtiar \& Asriani, 2015). In addition, (Santrock, 2010) states that stress might be handled by implementing the strategies which focus are on the problem solution ('Sunny' Hu \& Cheng, 2010). Then, according to (Carver, Scheier, \& Weintraub, 1989) the problem-focused coping strategy consists of five types namely: a) active coping, which refers to taking active actions in order to eliminate pressures or to improve the impact that has been resulted by the pressures; (b) planning, which refers to thinking about how to overcome the pressures; (c) suppression of competing activities, which refers to putting aside other problems, trying to avoid the distractions caused by the other events and even letting other problems appear to the surface in order to make peace with the previous problems; (d) restraint coping, which refers to waiting for the right moment to take actions, to hold one-self and to not take any unnecessary actions; and (e) seeking of instrumental social support, which refers to gathering suggestions, assistance or information from other people. Furthermore, Taylor in (Smet, 1994) divides the problemfocused coping strategy into three aspects namely: (a) confrontative coping, which refers to the act of solving problems by taking immediate actions although these actions might involve anger, emotion or even violence; (b) seeking social support, which refers to the act of gathering emotional support and information from the surrounding environment including suggestions, assistance, moral support and empathy; and (c) planful problem-solving, which refers to the act of making action plans and changing situations in order to solve the problems that have been encountered.

With regards to the strategy, several experts have proposed the factors that might influence the implementation of the problem-focused coping strategy. For example, (Lazarus \& Folkman, 1984) state that the factors that might influence the implementation of the problem-focused coping strategy are namely: (a) healthy and energy: a weak, sick and exhausted individual has lower energy level for implementing the coping strategy in comparison to a strong individual; (b) positive beliefs: an individual who positive self-perception will implement numerous skills for overcoming his or her problems; (c) problem-solving skills; (d) social skills: one of the social skills that should be possessed by any individual who implements the coping strategy is the communication skills; (e) social support; and (f) material resources: material resources include all material/physical forms that might influence individuals in implementing the coping strategy. On the other hand, according to (Pramadi \& Lasmono, 2003) the factors that might an individual in implementing the coping strategy are: (a) gender: women are more oriented toward their assignments in dealing with the problems and consequently they tend to implement less problem-focused coping strategy in dealing with their problems in comparison to men; (b) educational level: educational level might influence the cognitive development of an individual; and (c) age development: the capacity to respond to problems or difficulties will be different along with the age development, which changes the psychological structure of an individual.

The results of the study about the effectiveness of the problem-focused coping strategy and the emotion-focused coping strategy in improving the stress management of the students in Barru 1 State 
Psychology, Evaluation, and Technology in Educational Research, 2 (1), 2019, 3

Nurma Eliyah Mujahidah, Budi Astuti, Le Ngoc Ai Nhung

Senior High School by (Bakhtiar \& Asriani, 2015) show that both of the problem-focused coping strategy and the emotion-focused coping strategy have been effective in improving the stress management of the students in the state senior high school. In comparison to the results of this study, the researchers will only implement one variable, namely the problem-focused coping strategy, and the location of the senior high school under the study is the City of Yogyakarta.

Departing from the symptoms of the academic stress that the students have experienced, it is found that the problem-focused coping strategy has been less implemented in order to deal with the academic stress whereas it might be an effective tool for overcoming this type of stress. Not to mention, the influence of implementing the problem-focused coping strategy in dealing with the academic stress has been less disseminated. Therefore, through the present study the problem-focused coping strategy implemented will be tested in order to identify its influence on the decrease of the academic stress among the Grade VII students from the junior high school degree.

\section{METHOD}

The study was an experimental research. The experiment design that had been implemented was the quasi experiment using the non-equivalent control group design. This design was implemented in order to compare the decrease of the academic stress between the students that were provided with the problem-focused coping strategy and the students that were provided with the conventional strategy within the group guidance (Azahra, 2018).

The study took place from March until April 2019 in Negeri 2 State Junior High School Pleret located in Kedaton, Pleret, Pleret, Bantul. The population within the conduct of the study was all of the Grade VIII students and the total number of the population was 180 people. Then, the samples were selected by means of purposive sampling technique and the total number of the sample was 10 people from Grade VIII students whose pre-test results belonged to "Very High" and "High" category based on the academic stress scale assessment and who were willing to join the activities within the study. The ten 10 students were divided into two groups name: (a) the experimental group that later was provided with the special treatment, namely the problem-focused coping strategy; and (b) the control group that later was provided with the treatment from the school.

The procedures that had been implemented in the study were the pre-test activities by using the academic stress scale and the objective of these procedures was to identify the level of academic stress prior to the provision of the treatment. After the pre-test activities had been completed, the study progressed to the provision of the treatment namely the problem-focused coping strategy. At the end of the treatment, the post-test activities were administered in order to identify the level of academic stress between the experimental group and the control group, which was provided by the conventional treatment from the school. The data for the study were gathered by using the psychological scale. The psychological scale that had been implemented in the study was the academic stress scale, which had been the tool for measuring the level of academic stress that a student has (Dena, Arlizon, \& Umari, 2014).

According to (Arikunto, Suhardjono, \& Supardi, 2010), a good instrument should meet two important requirements namely being valid and being reliable. The validity of the research instrument within the study was tested by administering the content validity test and the construct validity test. (Sugiyono, 2010) states that content validity test aims at assessing the materials within the research instrument; furthermore, he states that content validity test is usually administered by an expert and thus this procedure is also known as expert judgment. Based on the results of the expert judgment on the academic stress scale, it was found that several statements should be revised in order to be compatible to the aspects and the indicators under assessment.

On the other hand, the reliability of an instrument shows that the instrument will generate the same data if the instrument is administered for measuring the same object in the different period of time (Sugiyono, 2010). Within the conduct of the study, the reliability of the instrument was tested by using the SPSS Version 16.00 application through the following features: analyse, scale, and reliability analysis. The results of the reliability test showed that the reliability score of the instrument within the study had been 0.882 ; therefore, it might be concluded that the instrument within the study had been reliable. 
Furthermore, the Wicoxon Test data analysis was also administered in the study. The Wilcoxon Test data analysis was administered in order to identify the influence of the treatment after the pre-test and after the post-test on the experimental group and the control group. Within the study, the administration of the Wilcoxon Test was performed by using the SPSS (Statistical Package for Social Science) 16.00 Version.

\section{RESULTS AND DISCUSSIONS}

\section{Description of General Data Profile with Regards to Academic Stress}

Table 1. General Description of Academic Stress Among the Grade VIII Students

\begin{tabular}{lcrr}
\hline \multicolumn{1}{c}{ Category } & Score Ranger & Frequency & \multicolumn{2}{c}{ Percentage } \\
\hline Very High & $\mathrm{X}>114$ & 1 & 0.56 \\
High & $96<\mathrm{X} \leq 114$ & 9 & 5.00 \\
Moderate & $79<\mathrm{X} \leq 96$ & 89 & 49.44 \\
Low & $61<\mathrm{X} \leq 79$ & 78 & 43.33 \\
Very Low & $\mathrm{X} \leq 61$ & 3 & 1.67 \\
Total & & $\mathbf{1 8 0}$ & $\mathbf{1 0 0 . 0 0}$ \\
\hline
\end{tabular}

The results in Table 1 show the complete description of the academic stress that the sampled Grade VIII students have experienced.

\section{Descriptive Data on the Pre-Test Results and the Post-Test Results for the Level of Academic Stress between the Experimental Group and the Control Group}

Pre-Test Data and Post-Test Data for the Level of Academic Stress in the Experimental Group

Table 2. The Pre-Test and the Post-Test Results for the Academic Stress of the Experimental Group

\begin{tabular}{cccccc}
\hline No. & Name & Pre-Test Score & Category & Post-Test Score & Category \\
\hline 1. & NL & 103 & High & 62 & Low \\
2. & PZ & 98 & High & 78 & Low \\
3. & AK & 102 & High & 64 & Low \\
4. & RG & 99 & High & 77 & Low \\
5. & HN & 98 & High & 78 & Low \\
\hline
\end{tabular}

Based on the results in Table 2, it is found that the post-test results display lower score than the pre-test results. In overall, the comparison between the pre-test results and the post-test results in the experimental group might be consulted in Figure 1.

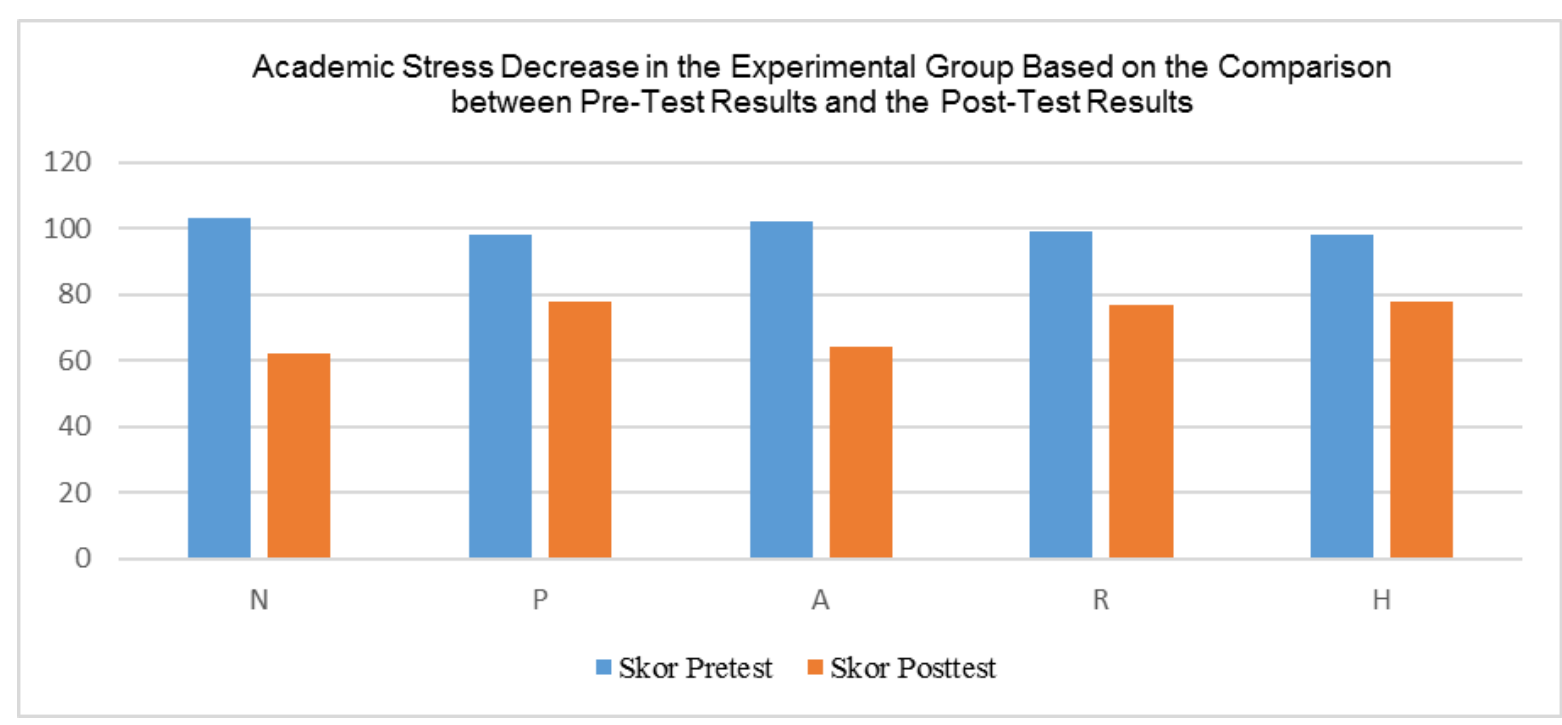

Figure 1. The Graphic on the Comparison between the Pre-Test Results and the Post-Test Results for of the Experimental Group 
Psychology, Evaluation, and Technology in Educational Research, 2 (1), 2019, 5

Nurma Eliyah Mujahidah, Budi Astuti, Le Ngoc Ai Nhung

Pre-Test Data and Post-Test Data for the Level of Academic Stress in the Control Group

Table 3. The Pre-Test and the Post-Test Results for the Academic Stress of the Control Group

\begin{tabular}{cccccc}
\hline No. & Name & Pre-Test Score & Category & Post-Test Score & Category \\
\hline 1. & DI & 134 & Very High & 135 & Very High \\
2. & DK & 107 & High & 107 & High \\
3. & MA & 99 & High & 100 & High \\
4. & YL & 106 & High & 106 & High \\
5. & AL & 97 & High & 102 & High \\
\hline
\end{tabular}

Based on the results in Table 3, it is found that there is not any significant change between the pre-test score and the post-test score. In overall, the comparison between the pre-test results and the post-test results in the control group might be consulted in Figure 2.

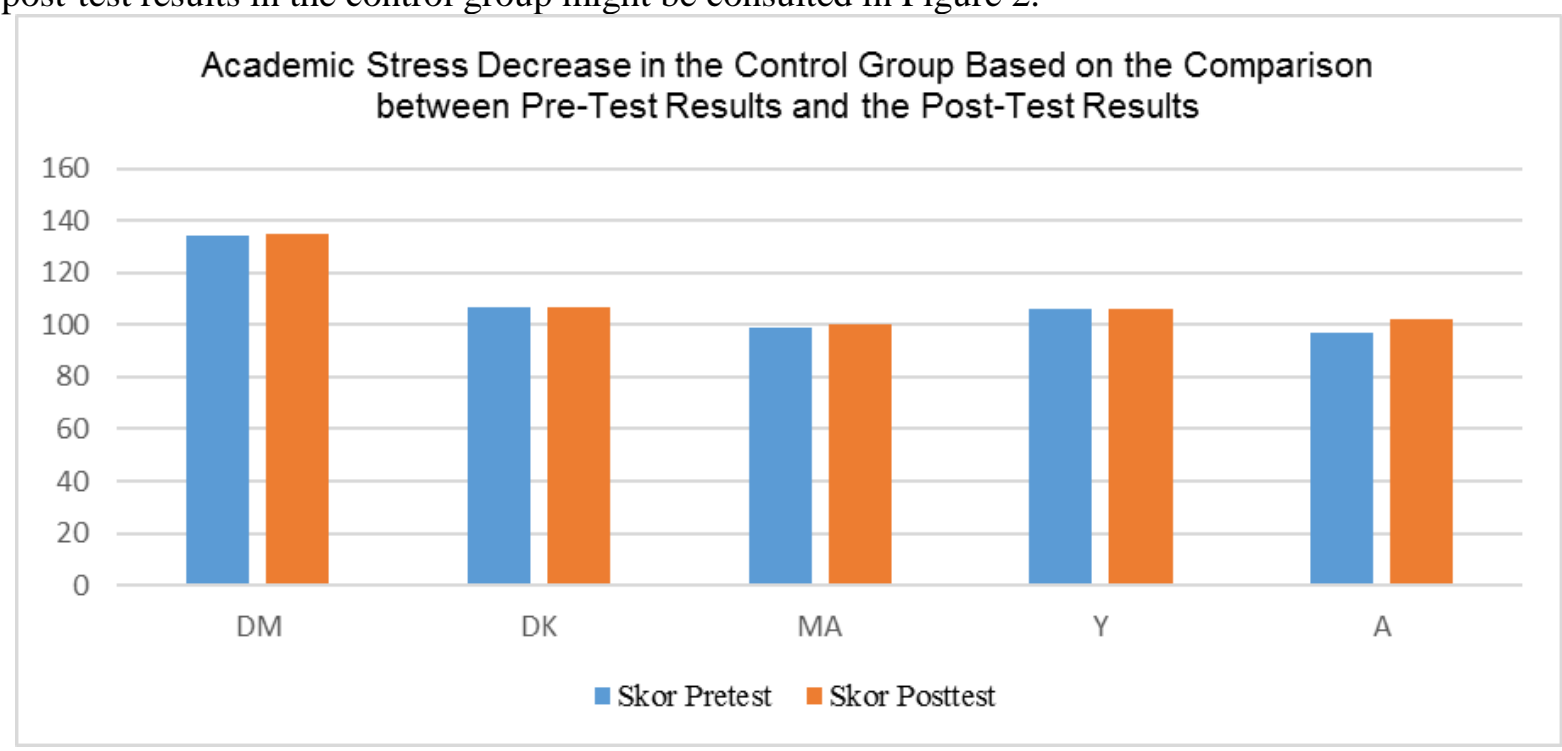

Figure 2. The Graphic on the Comparison between the Pre-Test Results and the Post-Test Results for of the Control Group

Then, the hypothesis test is performed in order to identify the influence of each treatment on the experimental group and the control group under the rate of significance 0.05 . The results of the hypothesis test for the experimental group and the control group are attained by means of Wilcoxon Test. The Wilcoxon Test itself is performed in order to identify the differences between the pre-test data and the post-test data. The results of the Wilcoxon Test for the variable academic stress within the experimental group might be consulted in Table 4.

Table 4. The Results of the Wilcoxon Test for the Variable Academic Stress of the Experimental Group

\begin{tabular}{lr}
\hline \multicolumn{2}{c}{ Test Statistics $^{\mathbf{b}}$} \\
\hline \multicolumn{1}{c}{ Post Test - Pre-Test } \\
\hline$Z$ & $-2.032^{\mathrm{a}}$ \\
Asymp. Sig. (2-tailed) & .042 \\
\hline
\end{tabular}

a. Based on positive ranks.

b. Wilcoxon Signed Ranks Test

From the results in Table 4, it is found that the Z-count within the experimental group is -.2032 and the significance value is 0.042 . These results show that there have been differences between the pre-test results and the post-test results after the treatment has been provided. Furthermore, in order to identify which results that have improved, data analysis is performed and the results of the data analysis might be consulted in Table 5 . 
Psychology, Evaluation, and Technology in Educational Research, 2 (1), 2019, 6

Nurma Eliyah Mujahidah, Budi Astuti, Le Ngoc Ai Nhung

Table 5. The Results of the Data Analysis for the Pre-Test and the Post-test of Academic Stress within the Experimental Group

\begin{tabular}{lcrrrr}
\hline \multicolumn{5}{c}{ Descriptive Statistics } \\
\hline Pre-Test & N & Minimum & Maximum & \multicolumn{1}{c}{ Mean } & \multicolumn{2}{c}{ Std. Deviation } \\
Post-Test & 5 & 98 & 103 & 100.00 & 2.345 \\
Valid N (listwise) & 5 & 62 & 78 & 71.80 & 8.075 \\
\hline
\end{tabular}

From the results in Table 5, it might be concluded that the mean score of the experimental group prior to the treatment is 100.00 while the mean score of the experimental group after the treatment is 71.80. In other words, the mean score prior to the treatment is lower than the mean score after the treatment. On the other hand, the results of the Wilcoxon Test for the control group might be consulted in Table 6.

Table 6. The Results of the Wilcoxon Test for the Variable Academic Stress within the Control Group

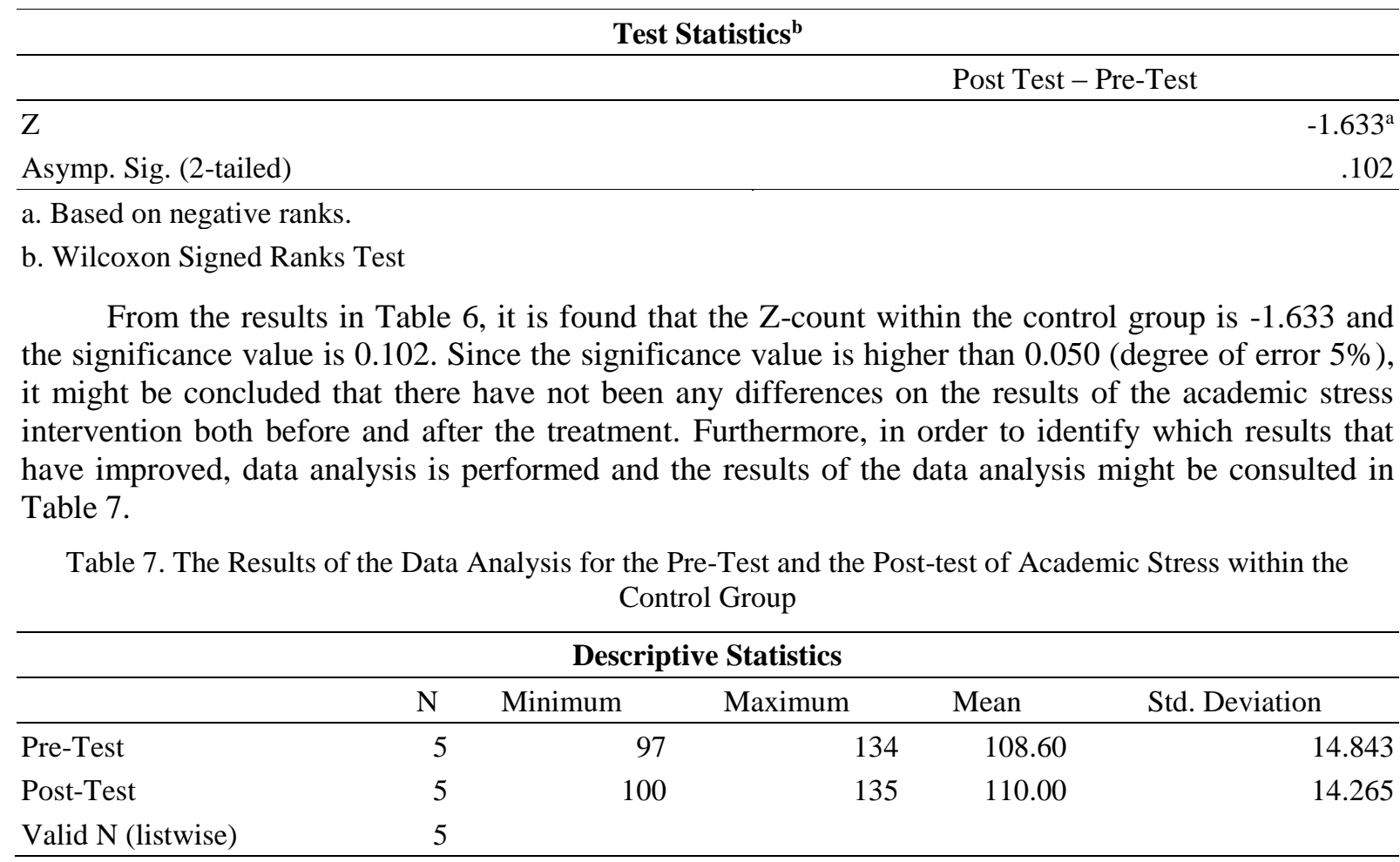

From the results in Table 7, it might be concluded that the mean score of the experimental group prior to the treatment is 108.80 while the mean score of the experimental group after the treatment is 110.00. In other words, there has been improvement after the treatment has been implemented.

From the results of the data analysis toward both groups, it might be concluded that the provision of problem-focused coping strategy has influence on the decrease of the academic stress among the Grade VIII students. in the same time, the results of the data analysis for both groups also show that there have been differences between the experimental group that has been provided with the problem-focused coping strategy and the control group that has been provided with the conventional coping strategy. In other words, the experimental group has decreasing level of academic stress while the control group has increasing level of academic stress.

\section{Descriptive Process of the Research}

Pre-Experiment

During the pre-experiment stage, the researcher administered the pre-test activities in order to observe the condition of the students' academic stress as the reference for the sample gathering activities. The pre-test activities were administered to the students from Grade VIIIA, VIIIB, VIIIC, 


\section{Psychology, Evaluation, and Technology in Educational Research, 2 (1), 2019, 7}

Nurma Eliyah Mujahidah, Budi Astuti, Le Ngoc Ai Nhung

VIIID, VIIIE, VIIIF and VIIIG; in total, the number of the students who had been involved in the pretest activities was 180 people. Out of 180 students in the pre-test activities, 1 student $(0.56 \%)$ belonged to the "Very High" category, 9 students (5.00\%) belonged to the "High Category," 89 students (49.94\%) belonged to the "Moderate" category, 78 students $(43.33 \%)$ belonged to the "Low" category and 3 students (1.67\%) belonged to the "Very Low" category.

After the pre-test data had been attained, the samples were gathered by implementing the purposive sampling technique and from the implementation 10 students who belonged to the "Very High" category and the "High" category had been attained. Then, the 10 students were assigned into two groups randomly. In total, 5 students were assigned into the experimental group and 5 students were assigned into the control group.

\section{Treatment Provision}

The treatment that had been provided was group guidance using the problem-focused coping strategy. The treatment was administered by adjusting the intensity and the meeting period to the situations and the subjects and also to the commitment of the subjects within the guidance process.

\section{Post-Experiment}

In this stage, a post-test was administered in order to identify the level of the students' academic stress after the treatment had been provided in the form of group guidance using the problem-focused coping strategy.

\section{Discussions}

The study is conducted under the title "Decreasing Academic Stress through Problem-Focused Coping Strategy for Junior High School Students" and has taken during the learning period in coordination with the teachers of Guidance and Counselling. Based on the data that have been gathered, it is found that the problem-focused coping strategy has influence on the decrease of academic stress. The level of the academic stress that has been high in the beginning of the study has decreased after the provision of the treatment.

With regards to the findings, several subjects have elaborated their academic stress. For example, NL and AK have suffered from academic stress due to the exhaustion caused by the school activities. Then, PZ has suffered from academic stress due to the friendship. Next, RG has suffered from academic stress due to the desire to start looking for employment and not continuing the school anymore, whereas HN has suffered from academic stress due to the confusion in continuing the school. The symptoms of the academic stress that these students have experienced are, namely, suffering from headache during the lesson, losing appetites and disliking the learning activities in the school.

During the group guidance activities, the students mutually provide their feedback from one to another by developing the problem-solving steps. In addition, the students also gradually develop good communication among the members so that the objective of the group guidance might be achieved. As having been proposed by (Hallen, 2005), the objective of group guidance service is to develop the communal steps for handling the problems that have been discussed within the group so that good relationship might be developed among the members along with good communication skills among individuals within the group and good understanding toward numerous situations and environmental conditions. In addition, the group guidance also aims at developing actual skills and actions in order to achieve the desires as having been uncovered in the group.

The provision of the treatment in the form of group guidance using problem-focused coping strategy has impacted the utilization of problem-solving strategies so that the students might decrease their academic stress. The statement is supported by the results of a study by (Bakhtiar \& Asriani, 2015) under the title "The Effectiveness of Problem-Focused Coping Strategy and Emotion-Focused Coping Strategy in Improving the Stress Management"; the results of their study show that both of the problem-focused coping strategy and the emotion-focused coping strategy has been effective in improving the stress management. Furthermore, the statement is also supported by the results of a study by (Retnowati, 2015) in her study under the title: "The Effectiveness of Problem-Focused Coping Strategy for Reducing the Learning Stress among the Accelerated Students of Public Madrasah Aliyah 3 Malang"; the results of her study show that the problem-focused coping strategy 


\section{Psychology, Evaluation, and Technology in Educational Research, 2 (1), 2019, 8}

Nurma Eliyah Mujahidah, Budi Astuti, Le Ngoc Ai Nhung

has been effective in reducing the learning stress among the accelerated students of Public Madrasah Aliyah 3 Malang.

Then, the results of the present study show that the problem-focused coping strategy that has influence on the decrease of academic stress might be influenced by several factors and one of them is health and energy. As having been proposed by (Lazarus \& Folkman, 1984), health and energy is an important factor since weak, sick and tired individuals will have lower energy in coping with the stress in comparison to healthy individuals. In relation to the statement, during the activities of group guidance, all of the students are healthy and therefore they are able to perform the activities of group guidance well.

In addition, positive belief is another factor that might influence the utilization of problemfocused coping strategy. During the activities of the group guidance, all of the students have positive self-perception and self-appreciation and, consequently, they are able to cope with their respective problems. According to (Lazarus \& Folkman, 1984), an individual who has positive self-perception will use a lot of skills for coping with his or her problems.

Furthermore, another factor that might influence the utilization of problem-focused coping strategy by an individual is gender. According to (Pramadi \& Lasmono, 2003), females tend to be task-oriented in dealing with their problems and the consequence is that females have less utilization of problem-focused coping strategy in comparison to males. However, the results of the present study show that the female students do not show lower level of problem-focused coping strategy utilization. This finding is apparent from the female students' level of the academic stress decrease that has been equal or even higher than the male students' level of the academic stress decrease. The reason is that the female students also have good health and energy and also positive belief.

The utilization of the problem-focused coping strategy provide stimulus for the counselees to find the solution that might be utilized for decreasing the academic stress. For example, some of the counselees have utilized the planful problem solving strategy and the seeking social support strategy in order to cope with the academic stress. According to Taylor in (Smet, 1994), the problem-focused coping strategy consists of, namely, active coping strategy, planful problem-solving strategy, suppression of competing activities strategy, restrain coping strategy, confrontative coping strategy and seeking social support strategy.

\section{CONCLUSION}

Based on the results of the study that has been conducted to the Grade VIII students, it might be concluded that the provision of problem-focused coping strategy in the group guidance has been able to help solving the problems that become the academic stress. The treatment in the from of problemfocused coping strategy has also been able to decrease the stress level from the "High" category to the "Low" category. Therefore, it might be concluded that the problem-focused coping strategy has influence on the decrease of academic stress among the Grade VIII students from junior high school.

\section{ACKNOWLEDGEMENT}

The researchers wish to thank the Dean of the Faculty of Education Science Universitas Negeri Yogyakarta and also the Principal of Public Junior High School 2 Pleret Bantul for their policy and maximum support so that the study might be completed.

\section{REFERENCES}

Arikunto, S., Suhardjono, \& Supardi. (2010). Penelitian tindakan kelas. Jakarta: Bumi Aksara.

Astuti, B., Purnama, D. S., \& Laksana, E. P. (2019). Stress reduction in thesis completion through peer tutoring method. Psychology, Evaluation, and Technology in Educational Research, 1(2), 73-81. https://doi.org/10.33292/petier.v1i2.23

Azahra, J. S. (2018). Hubungan antara stres akademik dengan coping stress pada mahasiswa yang sedang mengerjakan skripsi di fakultas pendidikan psikologi. UNIVERSITAS NEGERI JAKARTA.

Bakhtiar, M. I., \& Asriani, A. (2015). Efektivitas strategi problem focused coping dan emotion focused coping dalam meningkatkan pengelolaan stress siswa di SMAN 1 Barru. GUIDENA: 


\section{Psychology, Evaluation, and Technology in Educational Research, 2 (1), 2019, 9}

Nurma Eliyah Mujahidah, Budi Astuti, Le Ngoc Ai Nhung

Jurnal Ilmu Pendidikan, Psikologi, Bimbingan Dan Konseling, 5(2), 69. https://doi.org/10.24127/gdn.v5i2.320

Barseli, M., \& Ifdil, I. (2017). Konsep stres akademik siswa. Jurnal Konseling Dan Pendidikan, 5(3), 143. https://doi.org/10.29210/119800

Carver, C. S., Scheier, M. F., \& Weintraub, J. K. (1989). Assessing coping strategies: A theoretically based approach. Journal of Personality and Social Psychology, 56(2), 267-283. https://doi.org/10.1037/0022-3514.56.2.267

Dena, P. R. D. R., Arlizon, R. A., \& Umari, T. U. (2014). Pengaruh konseling kelompok terhadap pengurangan stres akademik siswa kelas X SMAN 2 Siakhulu TP 2014/2015. Jurnal Online Mahasiswa Fakultas Keguruan Dan Ilmu Pendidikan Universitas Riau, 2(2), 1-15. Retrieved from https://jom.unri.ac.id/index.php/JOMFKIP/article/view/6746

Hallen, A. (2005). Bimbingan dan konseling. In Jakarta: Quantum Teaching. Jakarta: Quantum Teaching.

Lazarus, R. S., \& Folkman, S. (1984). Stress, appraisal, and coping. Springer Publishing Company.

Mumpuni, Y., \& Wulandari, A. (2010). Cara jitu mengatasi stres. In Yogyakarta. Andi Offset. Yogyakarta: Andi Offset.

Nurmalasari, Y., Yustiana, Y. R., \& Ilfiandra, I. (2016). Efektivitas restrukturisasi kognitif dalam menangani stres akademik siswa. Jurnal Penelitian Bimbingan Dan Konseling, 1(1). https://doi.org/http://dx.doi.org/10.30870/jpbk.v1i1.1897

Pramadi, A., \& Lasmono, H. K. (2003). Koping stres pada Etnis Bali, Jawa, dan Sunda. Indonesian Psychological Journal, 4(17), 327-340.

Putwain, D. (2007). Researching academic stress and anxiety in students: some methodological considerations. British Educational Research Journal, 33(2), 207-219. https://doi.org/10.1080/01411920701208258

Retnowati, R. (2015). Efektivitas problem focus coping untuk mereduksi stres dalam belajar siswa akselerasi MAN 3 Malang. Universitas Negeri Malang.

Santrock, J. W. (2010). Adolescence: An introduction. New York, NY: Brown \& Benchmark.

Smet, B. (1994). Psikologi kesehatan. Jakarta: Grasindo.

Sugiyono. (2010). Metode penelitian kuantitatif kualitatif dan $R \& D$. Bandung: Alfabeta.

'Sunny' Hu, H.-H., \& Cheng, C.-W. (2010). Job stress, coping strategies, and burnout among hotel industry supervisors in Taiwan. The International Journal of Human Resource Management, 21(8), 1337-1350. https://doi.org/10.1080/09585192.2010.483867

Wardani, D. S. (2009). Strategi coping orang tua menghadapi anak autis. Indigenous: Jurnal Ilmiah Psikologi, 11(1). https://doi.org/https://doi.org/10.23917/indigenous.v11i1.1628 